\title{
Allelopathy as a potential strategy to improve microalgae cultivation
}

\author{
Leonardo Brantes Bacellar Mendes ${ }^{1}$ and Alane Beatriz Vermelho ${ }^{2,3^{*}}$
}

\begin{abstract}
One of the main obstacles for continuous productivity in microalgae cultivation is the presence of biological contaminants capable of eliminating large numbers of cells in a matter of days or even hours. However, a number of strategies are being used to combat and prevent contamination in microalgae cultivation. These strategies include the use of extreme conditions in the culture media such as high salinity and high pH to create an unfavorable environment for the competitive organisms or predators of the microalgae. Numerous studies have explored the potential of naturally occurring bioactive secondary metabolites, which are natural products from plants and microorganisms, as a source of such compounds. Some of these compounds are herbicides, and marine and freshwater microalgae are a source of these compounds. Microalgae produce a remarkable diversity of biologically active metabolites. Results based on the allelopathic potential of algae have only been described for laboratory-scale production and not for algae cultivation on a pilot scale. The adoption of allelopathy on microalgal strains is an unexplored field and may be a novel solution to improve algae production. Here we present information showing the diversity of allelochemicals from microalgae and the use of an allelopathic approach to control microalgae cultivation on a pilot scale based on R\&D activities being carried out in Brazil for biodiesel production.
\end{abstract}

Keywords: Microalgae, Allelopathy, Biodiesel, Contamination, Allelochemicals, Cultivation

\section{Introduction}

Currently, sustainability is a cornerstone in the management of natural resources. The availability of these resources, the environmental impacts, and the socioeconomic relationship resulting from their use in industrial processes need to be considered. The scarcity of fossil fuels has promoted a search for renewable and alternative low-cost energy sources [1]. Microalgae are organisms that have rapid growth rates and the ability to accumulate and synthesize 20 to $50 \%$ of their dry weight in neutral lipids, which are stored in the cytoplasm in the form of lipid bodies (lipid droplets) or lipid inclusions [2]. These features justify the use of microalgae for biodiesel production through the transesterification of lipids in a non-toxic and biodegradable process that may be chemical or enzymatic [3]. The use of microalgae

\footnotetext{
* Correspondence: abvermelho@micro.ufrj.br

2Department of General Microbiology, Institute of Microbiology Paulo de

Góes, Federal University of Rio de Janeiro, Rio de Janeiro, Brazil

${ }^{3}$ BIOTECHNOLOGY CENTER - BIOINOVAR: Bioenergy, Biocatalysis and

Bioproducts Unit, Federal University of Rio de Janeiro, Rio de Janeiro, Brazil

Full list of author information is available at the end of the article
}

might contribute to reduce the carbon dioxide emissions from fossil fuels, thus reducing the impact of global warming. Microalgae exhibit increased photosynthetic efficiency and higher growth rates than higher-order plants: they are capable of completing a growth cycle within a few days [4]. Oils from different origins have been used for producing biodiesel. Nevertheless, the cultivation of plants for oil extraction faces competition from the food and animal feed industries for the use and occupation of land [5]. The use of microalgae for biodiesel production has long been recognized and its potential has been reported in many recent studies and besides this, microalgae have multiple industrial applications [4,6-8]. However, current microalgal mass culture technologies have failed to produce bulk volumes of microalgal biomass at low costs due to contamination by biological pollutants [9]. The presence of contaminants is a major obstacle in biofuel production on an industrial level, especially in open-air ponds. The use of biocides and antimicrobial substances, with a selective spectrum for algae, protozoa, fungi, viruses, grazers and bacterial 
contaminants, is required to maintain continuous production and ensure quality control of these cultures. Allelopathy is a new approach and a promising strategy to achieve the goal of producing bulk volumes of microalgae. In this review we present information on the biotic and abiotic factors required for the cultivation of microalgae and discuss the current potential methods of contamination control, with an emphasis on the possible use of allelopathy and allelochemicals $[10,11]$.

\section{Cultivation of microalgae}

Microalgae constitute unicellular or multicellular organisms belonging to a group of prokaryotic or eukaryotic photosynthetic microorganisms that include cyanobacteria, blue-green alga (gram-negative bacteria), and green microalgae and diatoms [12]. Prokaryotic microalgae (cyanobacteria) lack membrane-bound organelles (plastids, mitochondria, nuclei, Golgi bodies, and flagella) whereas in eukaryotic microalgae, which include many different types of common algae, these organelles control cellular functions. It is estimated that there are more than 50,000 species of microalgae worldwide, among which about 30,000 have been studied [5]. Algae can either be autotrophic or heterotrophic. While autotrophic algae need inorganic compounds such as $\mathrm{CO}_{2}$, salts, and light as energy sources for growth, heterotrophic algae, which are non-photosynthetic, require external sources of organic compounds and nutrients for their energy supply. A third type of algae is mixotrophic as they have the ability to acquire exogenous organic nutrients or perform photosynthesis, depending on the environmental conditions [1].

The basic needs for the cultivation of microalgae are light, $\mathrm{CO}_{2}$, minerals, and water, but different factors may be involved in their growth depending on the species or strain. Microalgae may be cultivated in open systems or photobioreactors. Aside from carbon, in the form of carbon dioxide, microalgae require nitrogen, which is associated with their primary metabolism. Fast-growing species of microalgae prefer using ammonia instead of nitrate. Partial depletion of nitrogen is associated to lower growth rates and greater lipid production in microalgae. Lipids are synthesized as a reserve for situations of nutritional stress. Phosphorus is the third most important nutrient for algae and should be added to the medium in the form of phosphates. In addition to these components, trace metals such as $\mathrm{Mg}, \mathrm{Ca}, \mathrm{Mn}, \mathrm{Zn}, \mathrm{Cu}$, and $\mathrm{Mb}$, and vitamins are added to the culture medium for higher productivity $[4,5,13]$. Higher temperatures accelerate microalgae metabolism while lower temperatures lead to inhibition. The optimum temperature for many species of microalgae is in the $15-26^{\circ} \mathrm{C}$ range. Most microalgae prefer a neutral $\mathrm{pH}$, but Spirulina platensis, among other species, prefers a $\mathrm{pH}$ of 9.0 while others such as Chlorococcum littorale grow best at $\mathrm{pH}$ 4.0. Due to their fast growth rate, algae very quickly attain high densities. Thus, for light to reach these dense growths, stirring apparatuses to agitate the algae and cause water circulation are necessary [14].

\section{Open and closed cultivation systems}

A major bottleneck for the cultivation of microalgae for biofuel production is to achieve industrial-level production. This is necessary to make the process economically feasible and to ensure an uninterrupted supply for consumer markets [1]. Currently, most of the worldwide commercial production of microalgae is carried out in open ponds [15] (Figure 1).

Open systems, also known as "open ponds", have been much improved and have significant advantages over closed systems [1]. Additionally, the open systems are economically advantageous, but have problems of contamination from protozoa, viruses, other species of algae, fungi, and airborne micro-organisms, besides not allowing the control of the water temperature and light. The closed systems, called photobioreactors, which after numerous advances in materials engineering and applied biotechnology of the latest generation, are currently employed to produce fine chemicals (e.g., Astaxanthin), with a high added value (reaching up to U\$ $6,000.00 / \mathrm{kg}$ ) for commercialization. The main advantage of the photobioreactors is that the physical and nutritional parameters can be controlled $[6,16]$. Table 1 shows the advantages and disadvantages of each system.

\section{Biological contamination}

To be successful, engineering techniques applied to the construction and development of photobioreactors need to rely on the knowledge we have concerning the

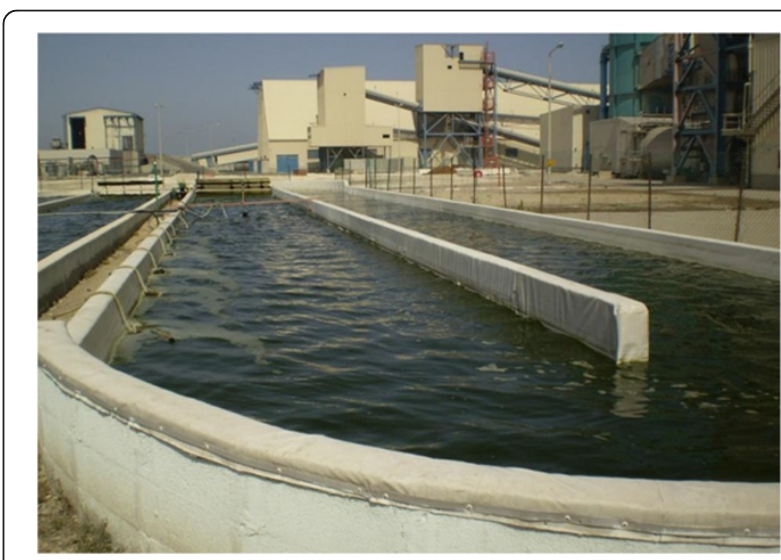

Figure 1 Cultivation of Nannochloropsis sp. microalgae using seawater in open systems at the Seambiotic company, Israel, 2009. 
Table 1 Comparison of cost and efficiency of open ponds and bioreactors for microalgae cultivation

\begin{tabular}{lll}
\hline Factors & Open ponds & Bioreactors \\
\hline Equipment & Low cost & High cost \\
Investment & Low & High \\
Operating Costs & Low & High \\
Maintenance and control of temperature & No cost but difficult & Easy but costly \\
Scaling up & Easy & Difficult \\
Agitation of large volumes of algae & Difficult, low uniformity, and low cost & Easy, high uniformity, and high cost \\
Evaporation of culture medium & High & Low \\
Risk of contamination & High & Reduced \\
Control of contamination & Difficult & Easy \\
Control of species & Difficult & Easy \\
Microalgae stress & Low & High \\
Maintenance and cleaning of the system & Easy & Difficult \\
Productivity & Low & High \\
\hline
\end{tabular}

behavior and microbiology of that particular strain of microalgae, including its genetic makeup and metabolic pathways. However, the cultivation of microalgae in open systems is only possible with the use of strategies that prevent biological contamination, predators/grazers, and parasites of various origins. We still know very little about the physiology and behavior of microalgae, and this field of biotechnology is still in its early stages. Additionally, the potential of culture contamination is a constant threat. Fungi, protozoa, and bacteria can cause contamination or other species of microalgae can enter the system and compete with the main microalgae [17]. Contamination can come from the air, dust particles, leaves, and other materials brought by the wind, as well as insects. These last are a major source of contamination.

Contaminants may not directly affect the production of algae but they may affect the $\mathrm{pH}$, which may lead to cultivation limitations. Some examples of biological contaminants were recently reported by JR Benemann at an international meeting held in Denver/USA (Algae Biomass Summit, 2012). He suggested that these contaminants were key issues to be studied and that better solutions to control them should be investigated. Contaminants found in open ponds include amoebae, ciliates, flagellates, rhizopods (protozoa), and other algae such as Oocystis sp. and Dunaliella viridis, Artemia and Parartemia (zooplankton), as well as viruses. Viruses are present in aquatic environments and can be found in association with both eukaryotic algae and cyanobacteria. Viral infection can reduce an algal population within a few days [9]. Insects of the order Diptera (flies and mosquitoes) and aquatic insects of the order Hemiptera (beetles) may also be present. Protozoa are predators rather than contaminants and some of them such as
Paramecium bursaria contain symbiotic cells of Chlorella sp. $[18,19]$. Cultivation in open ponds is susceptible to grazing by zooplankton, which can reduce algal concentrations and production to low levels within just a few days $[9,20]$. Among these zooplankton, ciliate [21], rotifer [22] cladoceran, and copepod [23] are the most common predatory species in microalgae cultivation [9]. The two types of feeding mechanism used by zooplankton have been observed in copepods: a passive (microalgae flowed into the copepod) and an active mechanism (copepod maxillae movement to bring in the microalgae). The copepods are able to alternate between the two mechanisms [24]. Grazing activities of zooplankton are also impacted by other factors, such as temperature and illumination [9]. Some species of bacteria, called phytoplankton-lytic bacteria, are able to inhibit the growth of microalgae and some of these species can cause mass destruction of the microalgae under cultivation. The attack depends on cell-to-cell contact or is mediated by extracellular compounds. Examples of such bacteria are Alteromonas sp., Flavobacterium sp., Cytophaga sp., Myxobacter sp., Bacillus sp., Pseudomonas sp., Saprospira sp. (SS98-5), and Pseudoalteromonas sp. $25[9,25]$.

\section{Strategies for contamination control}

Environmental pressure, chemical compounds, separation of contaminants, herbicides/pesticides and other chemical compounds are some of the strategies currently used to combat biological contamination and they are undergoing intense research and development worldwide (Figure 2). The establishment of a strong environmental pressure is a method widely used to control contaminants. Some microalgae are able to endure extreme conditions of cultivation and this may act as a 


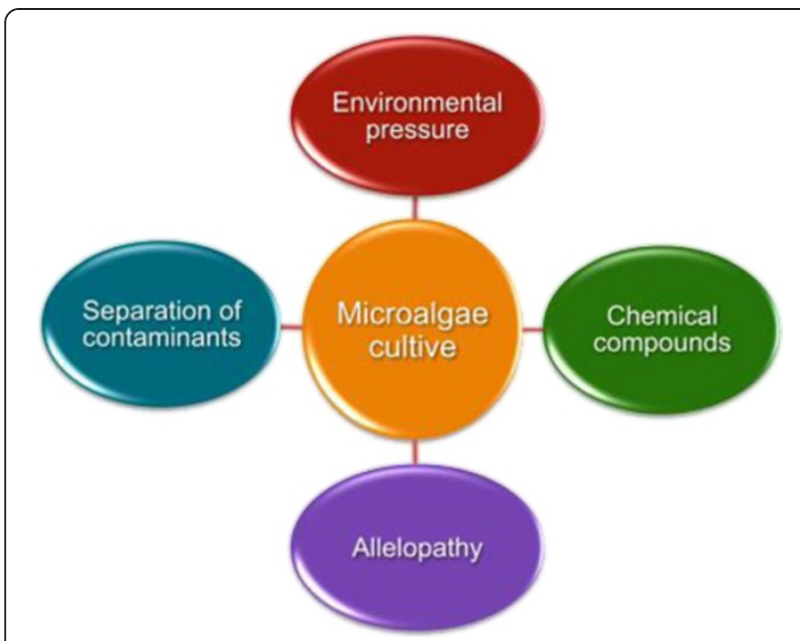

Figure 2 Strategies to control contaminants in microalgae cultivation.

competitive advantage in relation to contaminants in the liquid medium. An example is Dunaliella salina, which can grow in high concentrations of salinity, greater than $4 \%$ per mass [26]. The application of a specific stressor, such as a radical increase in the salinity of the microalgae medium, can damage the regulatory system of the predators without any loss of microalgae cells $[14,20]$. Reduction of the $\mathrm{pH}$ to 3.0 in a microalgae culture has been shown to kill flagellates [27]. Another method to combat biological contamination is to add chemical compounds that induce the biological contaminant to separate from the algal cells and it can then be concentrated in a special compartment of the photobioreactor from which it can be discarded.

Pesticides such as Trichlorphon, Decamethrin, Tralocythrin, and Buprofezin have also been used to annihilate zooplankton in microalgae suspensions [9]. Chemical compounds such as quinine sulfate and ammonia bicarbonate have been used to eliminate protozoa predators $[28,29]$. In some open-pond cultivation processes, an organic carbon substrate, such as acetate, is added continuously in small quantities in order to support higher biomass concentrations while it prevents excessive bacteria growth [30]. Microorganism contaminants can also be mechanically separated by size. Microalgae cells, which are normally smaller, are able to pass through a filter element that retains larger predators (e.g., rotifer contamination). Due to the relatively small size of microalgal cells, filtration can also be considered as an effective method to remove larger biological organisms, such as rotifers and copepods. Silk mesh screens have been used for this purpose, but rotifer eggs and the developing young individuals could not be removed completely [31].

\section{Allelopathy}

Allelopathy is a biological phenomenon by which an organism produces one or more biomolecules that affect the growth, survival, and/or reproduction of other organisms. These biomolecules, which are mostly secondary metabolites, are known as allelochemicals and are produced by certain plants, algae, bacteria, coral, and fungi. These compounds can have beneficial (positive allelopathy) or detrimental (negative allelopathy) effects on the target organism. Allelopathic interactions are an important factor in determining species distribution and abundance within plant and plankton communities. Biomolecules with allelopathic functions have other ecological roles, such as chemical defense, nutrient chelation, and in plants, regulation of soil biota [32-34]. These molecules could be used as natural herbicides and in recent decades allelopathy has been the target of much research in order to apply this biological phenomenon to promote pest control in crops for sustainable agriculture [35-39]. Allelochemicals produced by plants are a potential source for alternative agrochemicals and have become a new strategy. Several examples have been described such as an inhibition of $100 \%$ in the growth of the weed Gallium spurium with plant extracts [40] and the inhibitory effect of essential oils in algae, molds, and yeasts [32,33]. Sorghum produces sorgoleone a lipidic benzoquinone, which is currently used as a herbicide in agriculture [41].

Allelopathy studies have been carried out with microalgae, mostly focusing on negative allelopathy. For example, the dinoflagellate $P$. aciculiferum negatively impacts Synura petersenii (Chrysophyceae), Peridinium inconspicuum (Dinophyceae), Cyclotella sp. (Bacillariophyceae), Cryptomonas sp., and Rhodomonas lacustris (Cryptophyceae) through lysis. The allelopathic activity of $P$. aciculiferum may result from the impact of a single chemical or a cocktail of allelochemical molecules [42]. Microalgae allelopathy may negatively impact the performance of predators, leading to their death or inactivation. The strategy has been widely shown in toxic algae during blooming [10], and is an interesting approach for predator control. The most promising studies are those in which microalgae feed on the predators through already proven complex mechanisms such as phagotrophym. It is possible that some toxins are involved in prey capture. For instance, it has been observed that some phytoplankton such as Dinoflagellates paralyze the prey before ingestion $[34,43,44]$.

\section{Biotic and abiotic factors}

Allelopathy can be stimulated or minimized by a number of biotic and abiotic factors. Among the more important abiotic factors that enhance and stimulate allelopathy are deficiency of nutrients such as nitrogen 
and phosphorous compounds in the culture medium, low light intensities, low temperatures, and a culture medium with a high $\mathrm{pH}$ (around 9.0). Abiotic factors acting as repressors of allelopathy include high light intensities, high temperatures, excessive nutrients in the culture medium (nitrogen and phosphorus), and culture medium with low $\mathrm{pH}$ values ( $\mathrm{pH}$ around 6.0). The chemical structure of the toxic protein compounds and the mechanisms by which changes in abiotic factors stimulate or inhibit allelopathy have not yet been fully elucidated [45]. The most important biotic factors are the cellular concentrations of the microalgae producing toxic proteins, and the target cells. For example high concentrations of the microalgae Heterocapsa circularisquama and ciliates can bring about the death of the ciliates in an effect similar to "quorum sensing" $[42,45,46]$. Peridinium gatunense and the cyanobacteria Microcystis sp. have been shown to inhibit each other through allelopathy [47].

\section{Phagotrophy and osmotrophy}

Allelopathy can be further accompanied by processes of phagotrophy (ingestion of prey) and osmotrophy (ingestion of organic molecules) by microalgae without deactivation of the photosynthetic system. Some types of predatory species of microalgae present in zooplankton may serve as a source of nutrients in the cultivation of microalgae strains carrying a genetic potential for allelopathy. Some studies have shown even higher rates of growth in microalgae when they use osmotrophy and phagotrophy mechanisms, suggesting an intense energy use which seems to be related to the heterotrophic metabolism that some microalgae carry out. Among the many dinoflagellates that are able to carry out phagotrophy are Ceratium furca [48], Dinophysis acuminate [49], Gonyaulax polygramma [50], and Alexandrium tamarense [51].

\section{Major allelochemicals in microalgae}

Allelochemicals involved in the interactions between aquatic microalgae have received more attention in recent years. Allelopathy is an important factor for explaining community structure, dynamics of the populations, chemical defense of microalgae against potential microbes and micro-grazers in aquatic habitats, over and above the competition with other organisms for physical space, light and nutrients. The chemical defense against potential predators and grazers includes the larvae of aquatic invertebrates. These bioactive metabolites from microalgae provide a competitive advantage via interspecific and particularly negative (i.e., inhibitory) effects on growth, survival, and reproduction of the antagonist species. Besides this, they are a source of new antimicrobial agents, herbicides and biopesticides [52,53].
Microalgae produce a remarkable diversity of biologically active metabolites. Some allelochemicals from marine and freshwater microalgae are herbicidal compounds [52]. Secondary metabolites of the microalgae include every chemical class of natural product, ranging from fatty acids to alkaloids, as well as many peptides and amino acids $[53,54]$. The production of toxins by phytoplankton is also well known. Dinoflagellates can produce the toxin brevetoxin, a cyclic polyether compound, and Ciguatoxin, a carbon polycyclic compound that activates the $\mathrm{Na}^{+}$channel. Studies have shown that Karenia brevis, which produces brevetoxin, can affect the fertility of a copepod predator $[46,55,56]$. However, it is not yet clear whether this effect is a direct cause of the exposure to the microalgae toxin or the result of the poor nutritional value of $K$. brevis [57]. Saxitoxin is a neurotoxic alkaloid that blocks the $\mathrm{Na}^{+}$channel [58]. Domoic acid, which is a structural analog of kainic acid and proline, is produced by diatoms, and causes neuronal depolarization [59]. In some cases, heterotrophic bacteria can degrade toxins produced by phytoplankton [60] Another example is the cyanobacterium algae that produce the anatoxin-a (bicyclic secondary amine) and the microcystin-LR (cyclic heptapeptide) toxins that paralyze the motile green alga Chlamydomonas, leading to fast sedimentation of Chlamydomonas [45,61] (Figure 3). The metabolites belonging to the indole class of alkaloids have anti-algal activity, and consequently are associated with allelopathic interactions. The most cited allelochemicals from cyanobacteria are the hapalindoles and their related alkaloids [62,63].

Few studies have demonstrated the effects of microalgae allelopathic compounds against viruses. However, inhibitory activities of methanol extracts from the microalgae Ankistrodesmus convolutus, Synechococcus elongatus, and Spirulina platensis against Epstein-Barr virus (EBV) have been reported. The extracts reduced the cell-free EBV DNA, indicating that the lytic cycle or the release of the viruses could be inhibited [64]. Polysaccharides have been poorly investigated as allelopathic agents, both in aqueous and terrestrial ecosystems [36] but polysaccharides from Navicula directa, Gyrodinium impudicum, Ellipsoidon sp., Cryptomonads, Cochlodinium polykrikoide and a Pheophorbide like compound from Dunaliella primolecta have antiviral activities [65]. This section describes the major microalgae allelochemicals and Table 2 summarizes the major types with their major targets.

\section{Aldehydes}

Oxylipins are derived from the oxidation of fatty acid. Polyunsaturated aldehydes (PUAs) are the most toxic oxylipins and were first discovered in marine and freshwater diatoms. Other oxylipins are hydroxy acids and 

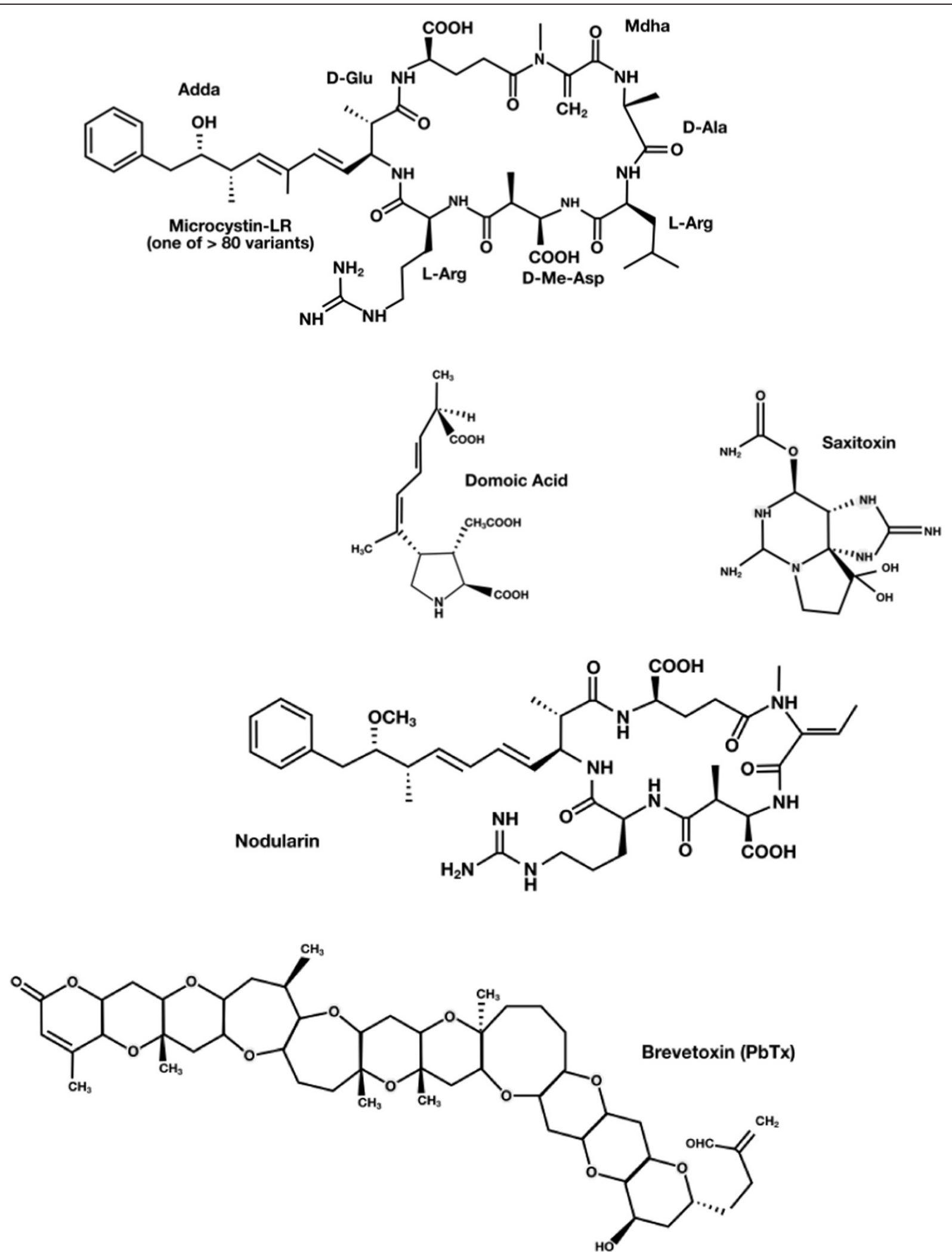

Figure 3 (See legend on next page.) 
(See figure on previous page.)

Figure 3 Structures of toxins from marine and freshwater microalgae. Based on Berry, 2011 [53]. Microcystin-LR is a cyclic heptapeptide produced by Cyanobacteria; Domoic acid is a structural analog of kainic acid and proline produced by Dinoflagellates; Saxitoxin is a neurotoxic alkaloid produced by dinoflagellates, Nodularin cyclic peptide is produced by the cyanobacterium Nodularia sp., and brevetoxin is represented by a cyclic polyether compound.

epoxy alcohols but the PUA decadienal is the most studied PUA. The molecule has an effect on the grazer defense of diatoms against copepods [78]. The PUAs 2E,4E-decadienal, 2E,4E-octadienal and 2E,4E-heptadienal, have a toxic allelopathic effect on chlorophyte Tetraselmis suecica, the diatom Skeletonema marinoi and on the dinoflagellate Amphidinium carterae [80]. In diatoms, aldehyde (2E,4E/Z)-decadienal induced a process of cellular signaling. Decadienal can trigger intracellular calcium transients and generate nitric oxide (NO) by a calcium-dependent NO synthase-like activity, resulting in cell death [81]. Besides this, antibacterial activity of these compounds has been described by [82].

\section{Glycolipids and fatty acids}

Allelopathic compounds have been described for the green algae Botryococcus braunii, favoring its dominance in its natural environment. The compounds are a mixture of free fatty acids including $\alpha$-linolenic, oleic, linoleic, and palmitic acids. The fatty acids become toxic to phytoplankton only when they are liberated by $B$. braunii to extracellular medium. In habitats with a $\mathrm{pH}$ between 8.0 and 9.0 fatty acids exist in a free form, namely $\mathrm{RCOO}^{-}$, a form known to be more toxic to aquatic organisms than uncharged forms inhibiting electron transport in chloroplasts [70,83]. Phytoplankton and zooplankton including Diatoms, Dinoflagellates,

Table 2 Allelochemicals and target

\begin{tabular}{llll}
\hline Compounds & Organism & Target & Reference \\
\hline Phenolic compounds & & & \\
$4,4^{\prime}$-dihydroxybiphenyl & Nostoc insulare Geitlerinema sp. & Cyanobacteria Bacteria & Fungi
\end{tabular}

Fatty acid

Timnodonic acid and stearidonic acid

a-linolenic, oleic, linoleic, and

palmitic acids

Red algae : Neodilsea yendoana, Palmaria palmata, Chondrus yendoi, and Ptilota filicina

Botryococcus braunii

\section{Alkaloids}

Nostocarboline

Dimers of Nostocarboline

12-epi-hapalindole E isonitrile

12-epi-hapalindole $F$

Ambiguines Ambiguine $\mathrm{H}$ isonitrile and Fischerella sp. ambiguine I isonitrile)

Calothrixin

Fischerellins A

Welwitindolinones

Peptides

microcystin-LR

Polyunsaturated aldehydes (PUAs)

Decatrienal

Octatrienal and Heptadienal

Calaothrix sp

Fischerella $\mathrm{sp}$

Hapalosiphon welwitschii Westiella intricata

Cyanobacteria

Diatom (Thalassiosira sp.)

Diatomn (Skeletonema marinoi Thalassiosira sp)
Chlamydomonas reinhardtii,

Copepods Phytoplankton Bacteria

Eukaryotic microalgae red tide planktons (Chattonella antiqua )

Copepoda (Nauplius sp., Eodiaptomus sp., Cyclopina sp. Cladocera (Bosmina sp., Diaphanosoma sp.) Rotifera (Keratella sp).

Microcystis aeruginosa Kirchneriella contorta

Gram positive (methicillin-resistant Staphylococcus aureus

Escherichia coli Microcystis (strains NPLS 1, NPJB 1 and CENA 62) Synechococcus PCC 7942.

Escherichia coli ESS K-12 Staphyloccocus albus a Bacillus subtilis a Saccharomyces cereisiae Candida albicans

Bacillus subtilis Plasmodium falciparum

Synechococcus PCC 7942.

Antifungal and insecticidal activity

Copepods Phytoplankton

Antibacterial activity against Staphylococcus epidermis
[79] Synechococcus Gram- negative bacteria

$[68,69]$

Terpenoids

Comnostins

Nostoc commune 
Chrysophyceae, red and brown algae produce fatty acids. Other effects such as membrane disruption and formation of oxidation product, antimicrobial activity, secondary messengers for biochemical pathways, and phospholipase action have been reported $[84,85]$.

Sulfated galactosyl (i.e. sulfoquinovosyl) a glycolipid from the thylakoid membranes of prokaryotic and eukaryotic photoautotrophs has inhibitory activity to eukaryotic DNA polymerase and is an anti-cancer agent [86].

\section{Phenolic compounds}

Phenolic compounds have substantial allelopathic applications in agriculture and forestry as herbicides, insecticides, and fungicides [87], Some aquatic plants are algaecidal such as as Schoenoplectus lacustris [88] and Myriophyllum spicatum producing respectively, benzoic and protocatechuic acid and Gallic, ellagic and pyrogallic acids. The effects of these phenolic compounds have been studied to control the algal bloom. It is interesting to note that the allelopathic compounds show spectra of action specific to determined groups of organisms allowing the modulation of their effects and action [89].

\section{Alkaloids}

A number of metabolites belonging to the indole class of alkaloids have been found to possess anti-algae activity, associated with allelopathy. Indeed, the most frequently cited allelochemicals from cyanobacteria are the hapalindoles and related alkaloids: 12-epi-hapalindole and isonitrile, including ambiguines, welwitindolinones and fischerindoles that have been isolated from both marine and freshwater representatives of the family Stigonemataceae, and particularly the genera Hapalosiphon sp. and Fischerella sp. [53].

\section{Oligopeptides and cyclic peptides}

Microcystins produced by the cyanobacteria are cyclic hepta-hepatopeptides belonging to the group of cyanotoxins. Extracellular products made by the cyanobacterium Anabaena flos-aquae contained both anatoxin and microcystin, and significantly reduced the growth of Chlamydomonas reinhardtii, a green alga. Besides this, high concentrations of $C$. reinhardtii extracellular products completely inhibited microcystin accumulation. These results demonstrate that cyanobacterial toxin production may be regulated by a complex mechanism involving growth phase dependence and environmental conditions [61] (Another compound is Portoamide which is a cyclic peptide produced by Chlorella vulgaris. Thus metabolites differentially inhibited some cyanobacteria, including Cylindrospermopsis raciborskii. Other cyanobacteria such as Microcystis sp, Aphanizomenon sp and Anabaena sp. and microalgae (e.g. the diatom, Cyclotella menenghiniana) tested were not inhibited [90].

\section{Lactones}

Cyanobacterin is a chlorinated $\gamma$-lactone, from Scytonema, a genus of photosynthetic cyanobacteria, which specifically inhibited a range of microalgae, including cyanobacteria and green algae, at micromolar concentrations [91]. The action mechanisms is the inhibition of photosystem II [92].

\section{Inhibitory effects of allelochemicals Enzyme inhibition}

Enzymes are essential for all organisms catalyzing multiple functions. Microalgae including cyanobacteria produce glycosidase and peptidase inhibitors [93]. Researchers in Taiwan described that $20 \%$ of the cyanobacteria isolates from biofilms possess a glucosidase inhibitory activity, an allelopathic activity and grazer toxicity [94]. The inhibitors are hydrolyzable polyphenols which complex with proteins, inhibiting the enzymes [95]. An extracellular, low molecular weight $\alpha$-amylase inhibitor was isolated from Anabaena. Tannins are stored in vacuoles of filamentous chlorophyte, and can inhibit activities of peroxidase (POD), catalase and cellulose $[93,96]$. Phenolic allelochemicals such as chlorogenic acid, caffeic acid and catechol can inhibit activities of phosphorylase; cinnamic acid and its derivatives can inhibit the hydrolysis activities of ATPase [97].

\section{RNA synthesis, DNA replication and protein synthesis}

The alkaloids 12-epi-hapalindole E isonitrile and Calothrixin A are algicidal metabolites isolated respectively from the cyanobacterial Fischerella sp and Calaothrix sp. (Table 1). Both of them have been demonstrated to inhibit the RNA synthesis, and consequently protein synthesis, in intact cells of Bacillus subtilis. These compounds inhibited Escherichia coli RNA polymerases directly. The indolophenanthridine calothrixin A from cyanobacterium Calothrix species inhibited DNA replication [74].

\section{Photosynthesis}

The cyanobacteria Fischerella muscicola produces fischerellin A (Table 2), a toxic allelochemical compound and potent photosystem-II inhibitor acting against other cyanobacteria and photoautotrophic organisms [98]. The crude lipophilic extracts containing indole alkaloids from Fischerella sp. strain 52 inhibit photosynthesis of the green alga Chlamydomonas sp. in a concentration- and time-dependent manner, causing loss of ultra-structural cell organization [62]. The aquatic monocotyledonous angiosperm, Lemna minor has been utilized as a model system for algae derived herbicides. Lemna minor was used to identify herbicidal compounds from ethanol extracts of the cyanobacterial species, Lyngbya aesturii. The herbicidal activity was due to the fatty acid, 2,5- 
dimethyldodecanoic acid which inhibited growth at a concentration of $200 \mathrm{ng} / \mathrm{mL}$ [99]. In lemma minor Microcystin inhibited growth, photosynthesis and oxidative stress [100].

\section{Toxin-assisted micropredation}

This phenomenon was observed in blooms of Prymnesium parvum, a flagellated alga. These microalgae have caused massive killings of fish around the world due to the release of allelochemicals. The study demonstrated the effects of Prymnesium on grazing zooplankton. Toxins are released during cell-to cell-contact in a mechanism called "toxin-assisted micropredation" [101].

\section{Allelochemicals for the industrial cultivation of microalgae}

Microalgae have many applications in biotechnology, biofuels, pharmaceuticals, the food industry and aquaculture [9]. Microalgae, or their derived-products, are also used in cosmetics and biofertilizers, in protein-rich animal feeds and chemical feedstocks [102]. The limiting factor for biodiesel production in open ponds with microalgae is contamination. New cultivation technologies have to be focused for industrial purposes using microalgae. The need for a biological method that is environmentally friendly for contamination management is increasing due to the problems associated with the constant and intensive use of chemical herbicides [39]. Besides this, natural herbicides exhibit a wider range of target sites than synthetic inhibitors. Studies with allelochemicals and their applications show the potential of natural products to be used to minimize contamination in microalgae cultures. It is a promising route for future applications. Further investigations need to be made in order to develop this important topic relative to the use of allelochemical compounds. At the present moment the cyanobacteria allelochemicals and algal toxins have been studied due to economic questions caused by the toxic algae bloom (HAB). In this context, allelopathy mediated by allelochemicals is an area with a wide range of biotechnological applications [35,53]. Another interesting use of bioactive compounds from microalgae is in biofouling. Biofouling is one of the more serious problems currently in maritime domains and affects the biofuels sector directly. Several substances with antifouling activity have been isolated from microalgae (mainly from cyanobacteria) such as fatty acids, lipopeptides, amides, alkaloids, terpenoids, lactones, pyrroles and steroids [103]. An example is the Cyanobacterin isolated from Scytonema hofmanni, which has been found to deter populations of the fouling benthic diatom Nitzschia pusilla [103]. The Ent-labdane diterpenes that are low polar compounds, could possibly play an ecological role such as antifouling compounds [36].

\section{Allelopathy: a potential novel strategy for contamination control}

Millions of liters of cultivation are lost due to biological contamination. In most cases, predators belonging to zooplankton grow rapidly, causing irreparable damage to the cultivation [10]. Problems concerning the incidence of fungi were reported in closed photobioreactors for the culture Haematococcus fluvialis. The solution was the addition of specific carbohydrates to the culture medium to compete with the preferred binding site of the fungus, a glycolipid found on the cell wall of the microalgae [104]. In the case of open ponds, significant losses of algae cultivation have been observed in a period of days or even hours. The researchers engaged in the combat and control of this type of situation must have

A

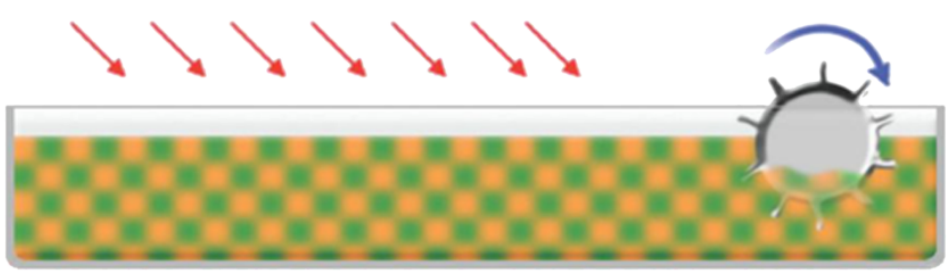

B

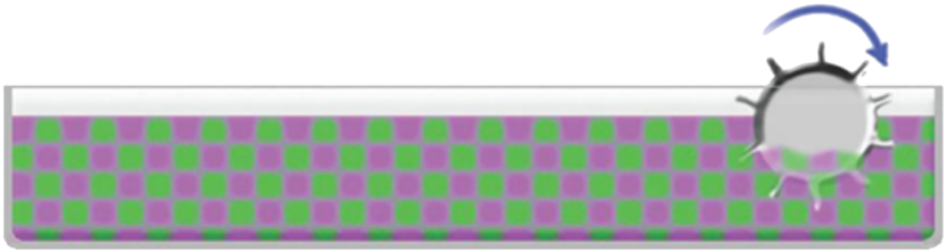

Figure 4 Control of biological contamination. A. Chemicals (red arrows) are released into the culture medium in order to combat biological contamination (orange) in an open system containing microalgae (green). The circle represents the blades turning at low speed for system circulation. B. Controlled management of allelopathy-derived compounds (magenta) from microalgae (green) eliminating biological contamination in open-pond cultivation. The circle represents the blades rotating at low speed for system circulation. 
specific training in algae culturing and be exceptionally well prepared. In a presentation at the "Algae Biomass Summit" in 2011, Hu highlighted that biological contamination may have a devastating effect on the population dynamics of microalgae, destroying tons of culture in mere days." In only six days the culture might be completely deteriorated by rotifers, ciliates, and vorticella" (Hu, 2011, personal communication). Using microalgae strains with a high capacity to combat predators and parasites is an extremely interesting possibility for scaling up processes carried out in open ponds, because the potential for failure or "crashing" of the crop production would be reduced. This possibility alone would fully justify the investments needed to better elucidate the mechanisms of allelopathy. An understanding of the biochemical communication processes involved in the microbial ecology of open ponds might allow us to find mechanisms to control contamination in algae cultivation $[9,20]$.

One of the classical approaches currently used and recommended by several authors to combat and prevent losses in algae cultivation includes adding specific chemical compounds (e.g., sodium hypochlorite) to the medium in order to combat predators (such as Protozoa). The use of biocide substances increases the cost in large-scale cultivation [15] (Figure 4). However, this approach entails additional financial costs and is laborintensive. A controlled approach that triggers allelopathy can be designed. Such a system would not give much opportunity for predation of the microalgae since the microalgae of interest would themselves eliminate the competitors and predators by feeding on them through phagotrophy in conditions of lack of nutrients in the culture medium (less nitrogen and phosphate compounds).

\section{A}

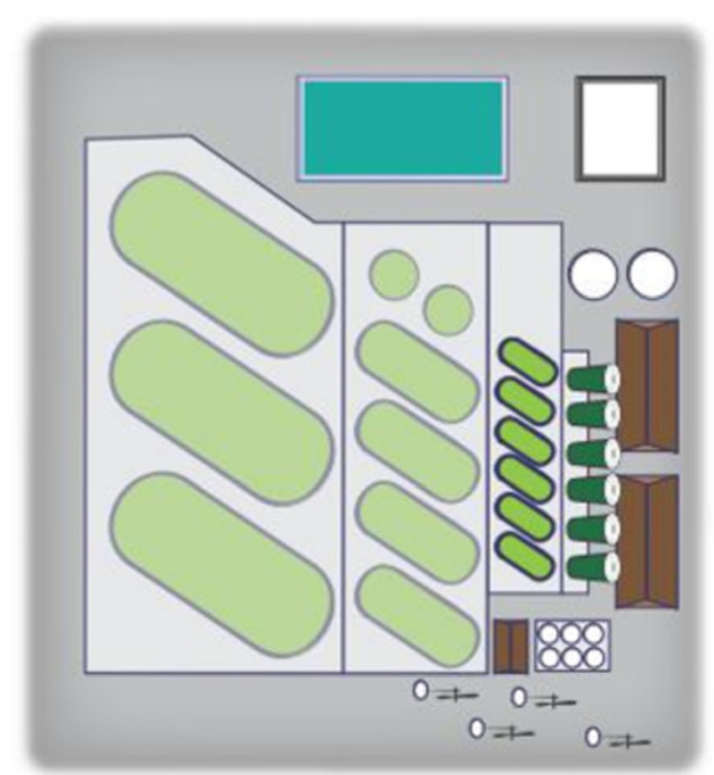

B

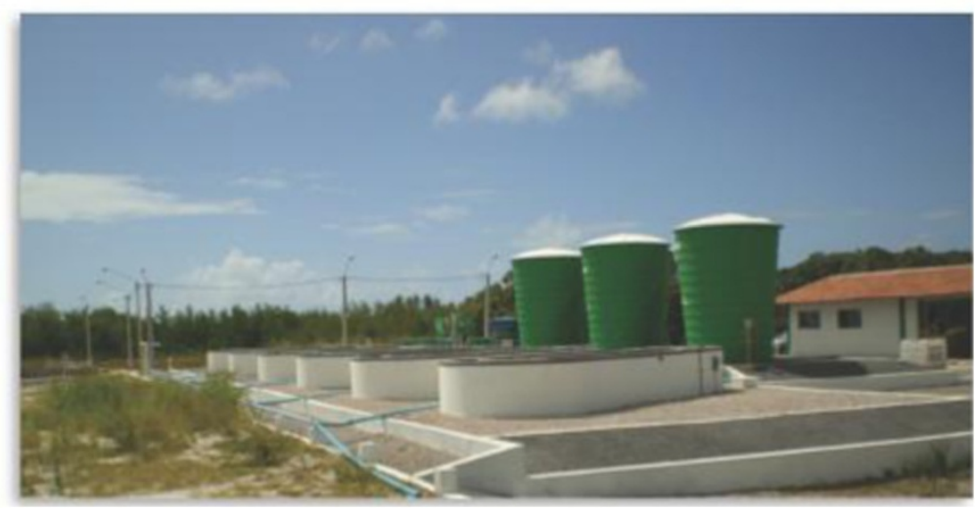

Figure 5 Microalgae pilot plant. A. Schematic diagram of the microalgae pilot plant for the production of biodiesel. At present the plant has the capacity to operate open ponds with a unit volume of 6,000 liters B. Photograph of the microalgae pilot plant for the production of biodiesel located in Extremoz at the Aquaculture Technology Center of UFRN (Universidade Federal do Rio Grande do Norte). Author's personal file, 2013. 
This strategy would result in an improved productivity and possibly financial savings due to the need to add fewer nutrients to the medium. In this case, deactivation of potential toxins in the culture medium through photo-oxidation or other processes before launching the culture medium into a disposal reservoir would be essential for biosafety and environmental protection. This innovative allelopathic approach could also draw on transgenic techniques to have genes inserted in microalgae strains of interest, making cultivation possible in the face of self-defense against competitors and predators. The allelopathic strategy has not yet been fully explored. Additionally, it requires rigorous control based on the laws and regulations of each country in order not to become a threat to the environment.

In Brazil, a potential strategy to help control biological contamination in algae cultivation would be the release of allelopathic compounds extracted from microalgae biomass (e.g., filtered extract of cyanobacteria) that occur naturally as harmful blooms impacting water quality in some regions of the country (Panosso, 2012, personal communication). However, for this strategy to be implemented, a very strict control process would be necessary due to the toxicity of these compounds.

CENPES-PETROBRAS (Petrobras Research Center, Brazil), in partnership with the Federal University of Rio Grande do Norte (UFRN) in Natal, Brazil, has been growing microalgae successfully on a pilot scale for biodiesel production since 2009 (Figure 5A,B). Currently, the capacity to operate open ponds that have a total area of $100 \mathrm{~m}^{2}$, producing 6,000 liters of algae culture has been achieved. The complete plant was launched in 2012 with the goal to produce sufficient microalgae biomass for biodiesel production, using native strains. Research into contamination control using different approaches has been the subject of $R \& D$ at CENPESPETROBRAS and includes studies of the allelopathic processes in microalgae cultivation. This project is essential for the scientific and technological development of the Northeast region. Quadrant winds and high luminosity throughout the year have allowed a successful production of microalgae biomass, ensuring high productivity in open ponds all year round. The biomass collected at this plant is stored at low temperatures before undergoing the extraction process and conversion into biodiesel.

\section{Conclusions}

The control of biological contamination is currently identified as one of the greatest obstacles to achieving positive results in the cultivation of microalgae in both open and closed systems. To scale up the cultivation of microalgae more data are needed on the mechanisms that stimulate or inhibit the production processes of allelopathic compounds by microalgae in cultivation systems, at lab, pilot, and commercial production scales. The development of this line of research could lead to innovative methods of cultivation in which low quantities of nutrients are needed and a strict control of predators is achieved in a more economical manner.

Apart from the data produced through research projects conducted in the lab, the scientific literature on the specific topic of allelopathy for microalgae cultivation is scarce. Thus, greater $R \& D$ investments in this field of biotechnology are needed.

Screening for, and selection, isolation, and maintenance of new microalgae species that are adequate for use with allelopathy strategies is of great importance for future studies to provide a better understanding of the causes and mechanisms involving predator and prey in microalgae cultivation systems, whether for the production of biofuels or other chemical compounds of interest. This is an Emerging Field but with a great potential for microalgae cultivation for biodiesel and other industrial applications.

\section{Abbreviations}

EBV: Epstein-Barr virus; PUAs: Polyunsaturated aldehydes; NO: Nitric oxide; POD: Peroxidase; HAB: Toxic algae bloom; PbTx: Brevidtoxin.

\section{Competing interests}

The authors declare that they have no competing interests.

\section{Authors' contribution}

This review was written by LBBM and ABV. Both authors read and approved the final manuscript.

\section{Acknowledgements}

This work was financially supported by CENPES-PETROBRAS (Petrobras Research Center). The authors wish to acknowledge the Brazilian National Council for Scientific and Technological Development (MCT-CNPq), Carlos Chagas Filho Foundation for Research Support in the State of Rio de Janeiro (FAPERJ), Coordination for the Improvement of Higher Education Personnel (CAPES), and the Brazilian Society of Microbiology (SBM). This manuscript was reviewed by a professional science editor and by a native Englishspeaking copy editor to improve readability.

\section{Author details}

${ }^{1}$ Leopoldo Américo Miguez de Mello Research and Development Center, CENPES, PETROBRAS, Rio de Janeiro, Brazil. ²Department of General Microbiology, Institute of Microbiology Paulo de Góes, Federal University of Rio de Janeiro, Rio de Janeiro, Brazil. ${ }^{3}$ BIOTECHNOLOGY CENTER BIOINOVAR: Bioenergy, Biocatalysis and Bioproducts Unit, Federal University of Rio de Janeiro, Rio de Janeiro, Brazil.

Received: 27 March 2013 Accepted: 16 October 2013

Published: 21 October 2013

\section{References}

1. Brennan L, Owende P: Biofuels from microalgae-A review of technologies for production, processing, and extractions of biofuels and co-products. Renew Sustain Energy Rev 2010, 14(2):557-577.

2. Rawat I, Ranjith- Kumar R, Mutanda T, Bux F: Dual role of microalgae: Phycoremediation of domestic wastewater and biomass production for sustainable biofuels production. Appl Energy 2011, 88:3411-3424.

3. Mutanda T, Ramesh D, Karthikeyan S, Kumari S, Anandraj A, Bux F: Bioprospecting for hyper-lipid producing microalgal strains for sustainable biofuel production. Bioresour Technol 2011, 102(1):57-70. 
4. Liu J, Huang J, Chen F: Microalgae as feedstocks for biodiesel production. In Biodiesel - Feedstocks and Processing Technologies. Edited by Stoytcheva M. Croatia: InTech; 2011:58-78.

5. Mata TM, Martins AA, Caetano NS: Microalgae for biodiesel production and other applications: a review. Renew Sust Energ Rev 2010, 14:217-232.

6. Lam MK, Lee KY: Microalgae biofuels: A critical review of issues, problems and the way forward. Biotechnol Adv 2012, 30(3):673-690.

7. Dassey AJ, Theegala CS: Harvesting economics and strategies using centrifugation for cost effective separation of microalgae cells for biodiesel applications. Bioresour Technol 2012, 128:241-245.

8. Halim R, Danquah MK, Webley PA: Extraction of oil from microalgae for biodiesel production: A review. Biotechnol Ad 2012, 30(3):709-732.

9. Wang H, Zhang W, Chen L, Wang J, Liu T: The contamination and control of biological pollutants in mass cultivation of microalgae. Bioresour Technol 2013, 128:745-750.

10. Tillmann U: Interactions between Planktonic Microalgae and Protozoan Grazers. J Eukaryot Microbiol 2004, 51(2):156-168.

11. Granéli E, Turner JT: Ecology of harmful algae. In Ecological Studies. 189th edition. Edited by Caldwell MM, Heldmaier G, Jackson RB, Lange OL, Levia DF, Mooney HA, Schulze E-D, Sommer U. Germany: Springer Berlin Heidelberg; 2006:1-413.

12. Graham JE, Wilcox LW, Graham LE: Algae. San Francisco, CA: Benjamin Cummings (Pearson); 2008:1-790.

13. Lardon L, Hélias A, Sialve B, Steyer JP, Bernard O: Life-cycle assessment of biodiesel production from microalgae. Environ Sci Technol 2009, 43:6475-6481.

14. Hu Q, Zarmi Y, Richmond A: Effects of light intensity, light path and culture density on output rate of Spirulina platensis (Cyanobacteria). Eur J Phycol 1998, 33:165-171.

15. Klein-Marcuschamer D, Chisti Y, Benemann JR, Lewis D: A matter of detail: assessing the true potential of microalgal biofuels. Biotechnol Bioeng 2013, 110(9):2317-2322.

16. MaBorowitzka L: Micro-algal biotechnology. In Micro-Algal Biotechnology. Edited by Pauw N, Persoone G. Cambridge: Cambridge University Press; 1988:197-221.

17. Patil V, Tran KQ, Giselrød HR: Towards sustainable production of biofuels from microalgae. Int J Mo Sci 2008, 9:1188-1195.

18. Van Etten J, Dunigan DD: Chloroviruses not your everyday plant virus. Trends Plant Sci 2012, 17(1):1-8

19. Day JG, Thomas NJ, Achilles-Day U, Leakey RJ: Early detection of protozoan grazers in algal biofuel cultures. Bioresour Technol 2012, 114:715-719.

20. Borowitzka MA: Commercial production of microalgae: ponds, tanks, tubes and fermenters. J Biotechnol 1999, 70:313-321.

21. Rosetta $\mathrm{CH}$, McManus GB: Feeding by ciliates on two harmful algal bloom species, Prymnesium parvum and Prorocentrum minimum. Harmful Algae 2003, 2(2):109-126

22. Lurling $M$, Beekman $W$ : Influence of food-type on the population growth rate of the rotifer Brachionus calyciflorus in short chronic assays. Acta Zool Sinica 2006, 52(1):70-78.

23. Frederiksen M, Edwards M, Richardson AJ, Halliday NC, Wanless S: From plankton to top predators: bottom-up control of a marine food web across four trophic levels. J Animal Ecol 2006, 75(6):1259-1268.

24. Vanderploeg HA, Paffenhofer G: Models of algal capture by the freshwater copepod Diaptomus sicilis and their relation to food-size selection. Limnol Oceanogr 1985, 30:871-885.

25. Shi SY, Liu YD, Shen YW, Li GB, Li DH: Lysis of Aphanizomenon folsaquae (Cyanobacteria) by a bacteria Bacillus cereus. Biol Control 2006, 39:345-351.

26. Shariati M, Hadi MR: Microalgal biotechnology and bioenergy in Dunaliella. In Progress in Molecular and Environmental Bioengineering - From Analysis and Modeling to Technology Applications. Edited by Carpi A. Croatia: InTech; 2011:483-505.

27. Liu ZG, Lu GL: The sterilizing studies of flagellate and ciliate in marine unicellular algae liquid. Zhanjiang Aquacult. Coll 1990, 2:36-41.

28. Moreno-Garrido I, Canäavate JP: Assessing chemical compounds forcontrolling predator ciliates in outdoor mass cultures of the green algae Dunaliella salina. Aquacult Eng 2001, 24:107-114.

29. Méndez C, Uribe E: Control of Branchionus sp. and Amoeba sp. in cultures of Arthrospira sp. Latin Am J Aquat Res 2012, 40(3):553-561.

30. Lee YK: Microalgal mass culture systems and methods: Their limitation and potential. J Appl Phycol 2001, 13:307-315.
31. Borowitzka MA: Culturing microalgae in outdoor ponds. In Algal Culturing Techniques. Edited by Andersen RA. New York: Academic Press; 2005:205-217

32. Yang $X$, Deng $S$, De Philippis $R$, Chen L, Hu C, Zhang W: Chemical composition of volatile oil from Artemisia ordosica and its allelopathic effects on desert soil microalgae, Palmellococcus miniatus. Plant Physiol Biochem 2012, 51:153-158.

33. Inderjit, Wardle DA, Karban R, Callaway RM: The ecosystem and evolutionary contexts of allelopathy. Trends Ecol Evol 2011, 26(12):655-662

34. Stoecker D, Tillmann U, Granéli E: Phagotrophy in Harmful Algae. In Ecological Studies, Ecology of Harmful Algae. 189th edition. Edited by Granéli E, Turner JT. Heidelberg: Springer Berlin; 2006:177-187.

35. Macias FA, Marin D, Oliveros-Bastidas A, Varela RM, Simonet AM, Carrera C, Molinillo JM: Allelopathy as a new strategy for sustainable ecosystems development. Biol Sci Space 2003, 17(1):18-23.

36. Macías FA, Molinillo JM, Varela RM, Galindo JC: Allelopathy-a natural alternative for weed control. Pest Manag Sci 2007, 63(4):327-348.

37. Farooq M, Bran K, Cheema ZA, Wahid A, Siddique KH: The role ofallelopathy in agricultural pest management. Pest Manag Sci 2011 67(5):493-506

38. Albuquerque MB, Santos RC, Ima LM, Filho PAM, Nogueira RJMC, Camara CAG, Ramos AR: Allelopathy, an alternative tool to improve cropping systems. A review. Agron Sustain Dev 2011, 31:379-395.

39. Sodaeizadeh $H$, Hosseini Z: Allelopathy and environmentally friendly method for weed control. In International Conference on Applied Life Sciences (ICALS) 10-12 September 2012. Turkey: In tech; 2012.

40. Uddin MR, Park KW, Pyon JY, Park S: Combined herbicidal effect of two natural products (sorgoleone and hairy root extract of tartary buckwheat) on crops and weeds. Aust J Crop Sci 2013, 7(2):227-233.

41. Santos ILVL, Silva CRC, Santos SL, Maia MMD: Sorgoleone: benzoquinona lipídica de sorgo com Efeitos alelopáticos na agricultura como herbicida. Arq Inst Biol 2012, 79(1):135-144.

42. Rengefors K, Legrand C: Broad allelopathic activity in Peridinium aciculiferum. Eur J Phycol 2007, 42(4):341-349.

43. Hansen PJ, Calado AJ: Phagotrophic mechanisms and prey selection in free-living dinoflagellates. J Eukaryot Microbiol 1999, 46:382-389.

44. Roberts EC, Legrand C, Steinke M, Wootton EC: Mechanisms underlying chemical interactions between predatory planktonic protists and their prey. J Plankton Res 2011, 33(6):833-842.

45. Granéli E, Edvardsen B, Roelke DL, Hagström JA: The ecophysiology and bloom dynamics of Primnesium spp. Harmful Algae 2012, 14:260-270.

46. Turner JT, Tester PA, Hansen PJ: Interactions between toxic marine phytoplankton and metazoan and protistan grazers. In Physiological Ecology of Harmful Algal Blooms. Edited by Anderson D, Cembella AD, Hallegraeff M. Germany: Springer Heidelberg; 1998:3-7.

47. Vardi A, Schatz D, Beeri K, Motro U, Sukenik A, Levine A, Kaplan A: Dinoflagellate-cyanobacterium communication may determine the composition of phytoplankton assemblage in a mesotrophic lake. Curr Biol 2002, 12:1767-1772.

48. Smalley GW, Coats DW, Stoecker DK: Feeding in the mixotrophic dinoflagellate Ceratium furca is influenced by intracellular nutrient concentrations. Mar Ecol Prog Ser 2003, 262:137-151.

49. Jacobson DM, Anderson DM: Widespread phagocytosis of ciliates and other protists by marine mixotrophic and heterotrophic thecate dinoflagellates. J Phycol 1996, 32:279-285.

50. Jeong HJ, Yoo YD, Seong KA, Kim JH, Park JY, Kim S, Lee SH, Ha JH, Yih WH: Feeding by the mixotrophic red-tide dinoflagellate Gonyaulax polygramma: mechanisms, prey species, effects of prey concentration, and grazing impact. Aquat Microb Ecol 2005, 38:249-257

51. Jeong HJ, Yoo YD, Park JY, Song JY, Kim ST, Lee SH, Kim KY, Yih WH: Feeding by the phototrophic red-tide dinoflagellates: 5 species newly revealed and 6 species previously known to be mixotrophic. Aquat Microb Ecol 2005, 40:133-150.

52. Macías FA, Galindo JLG, Garcia-Diaz MD, Galindo JCG: Allelopathic agents from aquatic ecosystems: potential biopesticides models. Phytochem Rev 2007, 7:155-178

53. Berry J: Marine and freshwater microalgae as a potential source of novel herbicides. In Herbicides and Environment. Edited by Kortekamp A. Croatia: In tech; 2011:705-734. 
54. Jones AC, Gu L, Sorrels CM, Sherman DH, Gerwick WH: New tricks from ancient algae: natural products biosynthesis in marine cyanobacteria. Curr Opin Chem Biol 2009, 13:216-223.

55. Collumb CJ, Buskey EJ: Effects of the toxic red tide dinoflagellate (Karenia brevis) on survival, fecal pellet production and fecundity of the copepod Acartia tonsa. In Edited by Steidinger KA, Landsberg JH, Tomas CR, Vargo GA. Petersburg: Florida Fish and Wildlife Commission; 2004. Harmful Algae 2002.

56. Paul VJ, Arthur KE, Ritson-Williams R, Ross C, Sharp K: Marine biological laboratory chemical defenses: from compounds to communities. Biol Bul 2007, 213:226-251.

57. Breie CF, Buskey EJ: Effects of the red tide dinoflagellate, Karenia brevis, on grazing and fecundity in the copepod Acartiatonsa. J Plankton Res 2007, 29:115-126.

58. Wiese M, D'Agostino PM, Mihali TK, Moffitt MC, Neilan BA: Neurotoxic alkaloids: saxitoxin and its analogs. Mar Drugs 2010, 8(7):2185-2211.

59. Turner JT, Tester PA: Toxic marine phytoplankton, zooplankton grazers, and pelagic food webs. Limnol Oceanogr 1997, 42:1203-1214.

60. Hulot FD, Huisman J: Allelopathic interactions between phytoplankton species: the roles of heterotrophic bacteria and mixing intensity. Limnol Oceanogr 2004, 49(4):1424-1434.

61. Kearns KD, Hunter MD: Toxin-producing Anabaena flos-aquae induces settling of Chlamydomonas reinhardtii, a competing motile alga. Microb Ecol 2001, 42:80-86.

62. Gantar M, Berry JP, Thomas S, Wang M, Perez R, Rein KS, King G: Allelopathic activity among cyanobacteria and microalgae isolated from Florida freshwater habitats. FEMS Microbiol Ecol 2008, 64:55-64.

63. Leão PN, Vasconcelos MT, Vasconcelos VM: Allelopathy in freshwater cyanobacteria. Crit Rev Microbiol 2009, 35:271-282.

64. Kok YY, Chu WL, Phang SM, Mohamed SM, Naidu R, Lai PJ, Ling SN, Mak JW, Lim PKC, Balraj P, Khoo ASB: Inhibitory activities of microalgal extracts against Epstein-Barr virus DNA release from lymphoblastoid cells. Zhejiang Univ Sci B 2011, 12(5):335-345.

65. Amaro HMA, Guedes C, Malcata FX: Antimicrobial activities of microalgae: an invited review. In Science against Microbial Pathogens: Communicating Current Research and Technological Advances, 3. Edited by Méndez-Vilas A. Spain: FORMATEX Microbiology Series; 2011:1272-1284.

66. Volk RB, Furkert F: Antialgal, antibacterial and antifungal activity of two metabolites produced and excreted by cyanobacteria during growth. Microbiol Res 2006, 161:180-186.

67. Caicedo NH, Kumirska J, Neumann J, Stolte S, Thöming J: Detection of bioactive exometabolites produced by the filamentous marine Cyanobacterium Geitlerinema sp. J Mar Biotechnol 2012, 14:436-445.

68. Suzuki Y, Takabayashi T, Kawaguchi T, Matsunaga K: Isolation of an allelopathic substance from the crustose coralline algae, Lithophyllum spp., and its effect on the brown alga, Laminaria religiosa Miyabe (Phaeophyta. J Exp Mar Biol Ecol 1998, 225:69-77.

69. Kakisawa H, Asari F, Kusumi T, Toma T, Sakurai T, Ohusa T, Hara Y, Chihara M: An allelopathic fatty acid from the brown alga Cladoshiphon okamuranus. Phytochemistry 1988, 27:731-735.

70. Chiang I-Z, Huang W-Y, Wu J-T: Allelochemicals of Botryococcus braunii (Chlorophyceae). J Phycol 2004, 40:474-480.

71. Volk RB: Screening of microalgal culture media for the presence of algicidal compounds and isolation and identification of two bioactive metabolites, excreted by the cyanobacteria Nostoc insulare and Nodularia harveyana, respectively. J Appl Phycol 2005, 17:339-347.

72. Blom JF, Blom JF, Brütsch T, Barbaras D, Bethuel Y, Locher HH, Hubschwerlen C, Gademann K: Potent algicides based on the cyanobacterial alkaloid nostocarboline. Org Lett 2006, 8(4):737-740.

73. Locher HH, Ritz D, Pfaff P, Gaertner M, Knezevic A, Sabato D, Schroeder S, Barbaras D, Gademann K: Dimers of nostocarboline with potent antibacterial activity. Chemotherapy 2010, 56(4):318-324.

74. Doan TN, Rickards RW, Rothschild JM, Smith GD: Inhibition of bacterial RNA polymerase by the cyanobacterialmetabolites 12-epi-hapalindole $\mathrm{E}$ isonitrile and calothrixin A. FEMS Microbiol Lett 2001, 196:135-139.

75. Etchegaray A, Rabello E, Dieckmann R, Moon DH, Fiore MF H, von Dohre H, Tsai SM, Neilan BA: Algicide production by the filamentous cyanobacterium Fischerella sp. CENA 19. J Appl Phycol 2004, $16: 237-243$

76. Raveh A, Carmeli S: Antimicrobial Ambiguines from the Cyanobacterium Fischerella sp. Collected in Israel. J Nat Prod 2007, 70:196-201.
77. Menéndez JC: Chemistry of the Welwitindolinones. Top Heterocycl Chem 2007, 11:63-101.

78. Ianora A, Bentley MG, Caldwell GS, Casotti R, Cembella AD, Engström-Öst J, Halsband C, Sonnenschein E, Legrand C, Llewellyn CA, Paldavičienë A, Pilkaityte R, Pohnert G, Razinkovas A, Romano G, Tillmann U, Vaiciute D: The relevance of marine chemical ecology to plankton and ecosystem function: an emerging field. Mar Drugs 2011, 9:1625-1648.

79. Jaki B, Orjala J, Heilmann J, Linden A, Vogler B, Sticher O: Novel extracellular diterpenoids with biological activity from the cyanobacterium Nostoc commune. J Nat Prod 2000, 63:339-343.

80. Ribalet F, Berges JA, lanora A, Casotti R: Growth inhibition of cultured marine phytoplankton by algal-derived polyunsaturated aldehydes. Aquat Toxicol 2007, 85:219-227

81. Vardi A, Formiggini F, Casotti R, de Martino A, Ribalet F, Miralro A, Bowler C: A stress surveillance system based on calcium and nitric oxide in marine diatoms. PLOS Biol 2006, 4:411-419.

82. Balestra C, Alonso-Sáez L, Gasol JM, Casotti R: Group-specific effects on coastal bacterioplankton of polyunsaturated aldehydes produced by diatoms. Aquat Microb Ecol 2011, 63:123-131.

83. Vedediktov PS, Krivoshejeva AA: The mechanism of fatty-acid inhibition of electron transport in chloroplasts. Planta 1983, 159:411-414.

84. Ikawa M: Algal polyunsaturated fatty acids and effects on plankton ecology and other organisms. UNH Center for Freshwater. Biol Res 2004, 6:17-44

85. Cantillo-Ciau Z, Moo-Puc R, Quijano L, Freile-Pelegrin Y: The tropica brown alga Lobophora variegata: a source of antiprotozoal compounds. Mar Drugs 2010, 16:1291-1304.

86. Mizushina Y, Kasai N, lijima H, Sugawara F, Yoshida H, Sakaguchi K: Sulfoquinovosylacylglycerol, a eukaryotic DNA polymerase inhibito and anti-cancer agent. Curr Med Chem Anticancer Agents 2005, 5:613-625.

87. Santana CM, Ferrera ZS, Padrón MET, Rodríguez JJS: Methodologies for the extraction of phenolic compounds from environmental samples: New Approaches. Molecules 2009, 14:298-320.

88. D'Abrosca B, DellaGreca M, Fiorentino A, Isidori M, Monaco P, Pacifico S: Chemical constituents of the aquatic plant Schoenoplectus lacustris: evaluation of phytotoxic effects on the green alga Selenastrum capricornutum. J Chem Ecol 2006, 2:81-96.

89. Nakai S, Inoue Y, Hosomi M, Murakami A: Myriophyllum spicatum-released allelopathic polyphenols inhibiting growth of blue-green algae Microcystis aeruginosa. Water Res 2000, 34:3026-3032.

90. Leão PN, Pereira AR, Liu WT, Ng J, Pevzner PA, Dorrestein PC, König GM, Vasconcelos VM, Gerwick WH: Synergistic allelochemicals from a freshwater cyanobacterium. Proc Natl Acad Sci 2010, 107(25):11183-11188.

91. Mason CP, Edwards KR, Carlson RE, Pgnatello J, Gleason RK, Wood JM: Isolation of chlorine-containing antibiotic from the freshwater Cyanobacterium Scytonema hofmanni. Science 1982, 213(4531):400-402.

92. Berry JP, Gantar M, Perez MH, Berry G, Noriega FG: Cyanobacterial toxins as allelochemicals with potential applications asalgaecides, herbicides and insecticides. Mar Drugs 2008, 15:117-146.

93. Gross EM: Allelopathy of aquatic autotrophs. Crit Rev Plant Sci 2003, 22:313-339.

94. Jüttner F, Wu JT: Evidence of allelochemical activity in subtropical cyanobacterial biofilms of Taiwan. Archiv für Hydrobiologie 2000, 147:505-517.

95. Haslarn E: Plant Polyphenols. vegetable tannins Revisited. Cambridge: Cambridge University Press; 1989

96. Winder JS, Canneli RJP, Walker JM, Delbarre S, Francisco C, Farmer PB: Glycosidase inhibitors from algae. Biochem. Soc 1989, 1989(17):1030-1031.

97. Ilori OJ, Ilori OO: Allelochemicals:types, activities and usage in Pest control. J Sci Sci Ed, Ondo 2012, 3(1):106-110.

98. Hagmann L, Jiittner F, Fischerellin A: a Novel Photosystem-Il-inhibiting Allelochemical of the Cyanobacterium Fischerella muscicola with antifungal and herbicidal activity. Tetrahedron Lett 1996, 37(36):6539-6542.

99. Entzeroth M, Mead DJ, Patterson GML, Moore RE: A herbicidal fatty acid produced by Lyngbya aestuarii. Phytochemistry 1985, 24:2875-2876.

100. Mitrovic SM, Pflugmacher S, James KJ, Furey A: Anatoxin-aelicits an increase in peroxidase and glutathione-S-transferase activity in aquatic plants. Aquat Toxicol 2004, 10:185-192.

101. Remmel EJ, Hambright KD: Toxin-assisted micropredation: experimental evidence showsthat contact micropredation rather than exotoxicity is the role of Prymnesium toxins. Ecol Lett 2012, 15:126-132. 
102. Raposo MF, de Morais RM, Bernardo de Morais AM: Bioactivity and applications of sulphated polysaccharidesfrom marine microalgae. Mar Drugs 2013, 11(1):233-252.

103. Bhadury P, Wright PC: Exploitation of marine algae: biogenic compounds for potential antifouling application. Planta 2004, 219:561-578.

104. Hoffman Y, Aflalo C, Zarka A, Gutman J, James TY, Boussiba S: Isolation and characterization of a novel chytrid species (phylum Blastocladiomycota), parasitic on the green alga Haematococcus. Mycol Res 2008, 112(1):70-81.

doi:10.1186/1754-6834-6-152

Cite this article as: Bacellar Mendes and Vermelho: Allelopathy as a

potential strategy to improve microalgae cultivation. Biotechnology for

Biofuels 2013 6:152.

\section{Submit your next manuscript to BioMed Central and take full advantage of:}

- Convenient online submission

- Thorough peer review

- No space constraints or color figure charges

- Immediate publication on acceptance

- Inclusion in PubMed, CAS, Scopus and Google Scholar

- Research which is freely available for redistribution 